\title{
Effect of Combination of Different Levels of Pruning, Nutrition and Paclobutrazol on Yield and Economics of Mango (Mangifera indica L.) cv. Alphonso
}

\author{
K. Usha Rani*, M.K. Honnabyraiah, J. DinakaraAdiga, T. Sakthivel, \\ Ashok, S. Alur and G.K. Halesh
}

Department of Fruit science, College of Horticulture, University of Horticultural sciences, Bangalore-560065, Karnataka, India

*Corresponding author

\section{A B S T R A C T}

Keywords

Mango cv.

Alphonso, Pruning,

INM, Paclobutrazol,

AMC (Arka

Microbial

Consortium)

Article Info

Accepted:

10 October 2019

Available Online:

10 November 2019
Alphonso is the best table variety of mango produced in India and has great demand in the global market owing to its keeping quality, aroma, texture and flavour. Due to its inherent physiological disorders, we have not been able to achieve the expected production. Keeping this in view, experiment was designed to find out suitable remedial measures to step up the production by using pruning, INM and plant growth regulators. Field investigation was conducted for two consecutive years (2017-18 and 2018-19) in the established mango orchard on 7 years old Alphonso mango trees and maintained at 5 X 5 $\mathrm{m}$ spacing at Regional Horticultural Research and Extension Centre, UHS campus, GKVK, Bengaluru, to investigate the effects of pruning, INM and PBZ on regulating yield. Higher number of fruits per panicle (2.52), less number of days to maturity (108.13), more number of fruits per tree (148.33), highest yield per tree $(27.58 \mathrm{~kg} /$ tree $)$ and highest benefit cost ratio (3.01) were recorded in trees pruned at $10 \mathrm{~cm}$ length along with soil drenching of PBZ @ $0.75 \mathrm{~g}$ a.i./ $\mathrm{m}$ canopy diameter, application of $75 \% \mathrm{RDF}$, AMC and mango special spray.

\section{Introduction}

Mango (Mangifera indica L.) is a delicious fruit and member of family Anacardiaceae, in the order Sapindales with chromosomal number $2 n=4 x=40$. It is one of the most important tropical fruit of the world and is the national fruit of India. Mango (Mangifera indica L.) is called 'the King of fruits' due to its wide adaptability, delicious taste, excellent flavor, attractive appearance and richness in phytochemical and nutrient (Purseglove, 1972). India has traditionally been the world's largest producer of mangoes and having area 
under cultivation of 22.5 lakh hectares with production 21.82 million tons with a productivity of 8.7 tons/ha (Anon, 2018). India has a rich wealth of mango germplasm with more than 1000 varieties grown throughout the length and breadth of the country. However, only about 21 of them like Alphonso, Banganapally, Chausa, Dashehari, Langra, Totapuri, Kesar etc., are commercially cultivated in different mango growing regions (Yadav, 1997).

Among them $c v$.Alphonso tops the list and is used as one of the choicest and prime variety of India. It is nutritionally accepted because of its characteristic sugar-acid blend, attractive colour and shape, pleasant aroma, superior fragrance, highly appreciable flavour, delicious taste and long keeping quality. In spite of these, 'Alphonso' is handicapped by its serious inherited physiological disorders like alternate bearing and occurrence of spongy tissue, which makes the variety as poorest yielder (2.5-3 tons/ha) compared to average Indian productivity ( 8.7 tons/ha). The alternate bearing is one of the major hurdles for its commercial spread.

The improvements in crop productivity in modern horticultural systems are increasingly dependent on manipulation of the physiological activities of the crop by pruning, nutrition and chemical means. The main reasons of low productivity are alternate bearing, malformation, fruit drop and insect pest and disease attack. It is observed that there is heavy fruit-drop at various stages of fruit growth which is a serious problem and has become a limiting factor for increasing production in Alphonso mango. With this view, the attempts are there for being made to study on effect of pruning, nutrition and paclobutrazolon regulation and increasing yield of Alphonso mango trees grown under the agroclimatic conditions of Bangaluru region.

\section{Materials and Methods}

The experiment was carried out an uniform trees (7-8 years) of cultivar Alphonso during 2017-18 and 2018-19 which are maintained at 5 X $5 \mathrm{~m}$ spacing at Regional Horticultural Research and Extension Centre, UHS campus, GKVK, Bengaluru,. Combinations of different levels of pruning, concentrations of paclobutrazol and levels of nutrition on regulation and increasing fruit yield of mango $c v$. Alphonso was investigated. The observations were recorded on three trees for each treatment. Combinations of different levels of pruning, nutrition and paclobutrazol were tried for their effect on yield and calculated the economics of the treatments along with control.

\section{Treatment details of the experiment}

$\mathrm{T} 1=$ control (No pruning and only RDF); T2 $=$ Shoot pruning at $10 \mathrm{~cm}$ length + RDF; T3 = Shoot pruning at $10 \mathrm{~cm}$ length + PBZ @ $0.75 \mathrm{~g}$ a.i./ $\mathrm{m}$ canopy diameter $+75 \%$ of $\mathrm{RDF}+5 \mathrm{~kg}$ vermicompost $+20 \mathrm{~g}$ of $\mathrm{AMC}+$ Mango special(spray); $\mathrm{T} 4=$ Shoot pruning at $10 \mathrm{~cm}$ length + PBZ @ 0.75g a.i./ m canopy diameter $+75 \%$ of $\mathrm{RDF}+10 \mathrm{~kg}$ vermicompost $+2 \mathrm{~g}$ of AMC + Mango special(spray); T5 = Shoot pruning at $10 \mathrm{~cm}$ length + PBZ @ 1.25g a.i./ m canopy diameter $+75 \%$ of $\mathrm{RDF}+5 \mathrm{~kg}$ vermicompost $+20 \mathrm{~g}$ of AMC + Mango special(spray); T6 = Shoot pruning at $10 \mathrm{~cm}$ length + PBZ @ 1.25g a.i./ m canopy diameter $+75 \%$ of $\mathrm{RDF}+10 \mathrm{~kg}$ vermicompost $+20 \mathrm{~g}$ of $\mathrm{AMC}+$ Mango special(spray); $\mathrm{T} 7=$ Shoot pruning at $20 \mathrm{~cm}$ length + RDF; T8 $=$ Shoot pruning at $20 \mathrm{~cm}$ length + PBZ @ 0.75g a.i./ m canopy diameter $+75 \%$ of $\mathrm{RDF}+5 \mathrm{~kg}$ vermicompost $+20 \mathrm{~g}$ of $\mathrm{AMC}+$ Mango special(spray); T9 $=$ Shoot pruning at $20 \mathrm{~cm}$ length + PBZ @ 0.75g a.i./ m canopy diameter $+75 \%$ of $\mathrm{RDF}+10 \mathrm{~kg}$ vermicompost $+20 \mathrm{~g}$ of AMC + Mango special(spray); T10 = Shoot pruning at $20 \mathrm{~cm}$ length + PBZ @ $1.25 \mathrm{~g}$ a.i./ m 
canopy diameter $+75 \%$ of $\mathrm{RDF}+5 \mathrm{~kg}$ vermicompost $+20 \mathrm{~g}$ of $\mathrm{AMC}+$ Mango special(spray); $\mathrm{T} 11=$ Shoot pruning at $20 \mathrm{~cm}$ length + PBZ @ 1.25g a.i./ m canopy diameter $+75 \%$ of $\mathrm{RDF}+10 \mathrm{~kg}$ vermicompost $+20 \mathrm{~g}$ of AMC + Mango special(spray).

\section{Treatment imposition for experiment}

This investigation was laid out in randomized complete block design (RCBD) with three replications. Two years data was statistically analysed and pooled data is interpreted here. Pruning was carried out in $3^{\text {rd }}$ week of July of year 2017 and 2018, application of paclobutrazol last week of September of year 2017 and 2018 and fertilizer application 2 split doses (first half dose in July of year 2017 and 2018 along with AMC, second half dose in October of year 2017 and 2018), mango special 3 sprays (before flowering, after flowering, during fruit setting) in year 2017 and 2018

\section{Results and Discussion}

\section{Number of fruits per panicle}

The data related to number of fruits per panicle are presented in Table 1. All the treatments showed significant effect on number of fruits per panicle during both years of research (2017-18 and 208-19). The pooled mean of two years data on number of fruits per panicle revealed that its maximum value (2.52) was registered with T4 (shoot pruned at $10 \mathrm{~cm}$ length along with the application of PBZ @ 0.75g a.i. / m canopy diameter, 75\% of RDF, $10 \mathrm{~kg}$ vermicompost, $20 \mathrm{~g}$ of AMC, mango special spray) which was at par with T9 (2.38), while minimum (0.73) was recorded in control followed by T2 (1.07).

Among the treatments, T4 recorded $(245 \%)$ more number of fruits per panicle compared with other treatments and control. Pruning resulted in reduced branching density and thus higher fruiting due to better light penetration into tree canopy that increases the photosynthetic efficiency and diverting the photosynthates towards fruit production has been reported by Jannoyer and Lauri (2009) and Elkhishen (2015). PBZ is reported to exert influence on overall tree physiology through improved nutrient uptake, partitioning photosynthates to the sites of flowering. This results are in confirmity with Sarkar and Rahim (2012) in mango $c v$. Amrapali, Upreti et al., (2013) in mango $c v$. Totapuri and Lina and Protacio (2015) in jackfruit. Deepasamanth et al., (2018) reported that with mango special spraying there is increased fruit yield and quality in Banganpally mango and concluded that improvement in number of fruits per panicle could be attributed to the B and $\mathrm{Zn}$ present in micronutrient treatments. Boron helps in fruit setting by enhancing the pollen grain germination and pollen tube elongation whereas, $\mathrm{Zn}$ reduces the fruit drop at various stages of fruit growth by promoting auxin synthesis which in turn delays the formation of abscission layer. Paclobutrazol appeared to favourably alter the source sink relationship of mango to support fruit growth with a reduction in vegetative growth (Kurianet al., 2001). Similar results were reported by Singh et al., (2009) and Singh et al., (2018) in mango $c v$. Amrapali.

\section{Days to maturity}

The data presented in Table 1 revealed that there is a significant impact of various treatments on days to maturity during both years of investigation (2017-18 and 2018-19). Pooled mean data showed minimum duration for days to maturity of fruit (108.73days) was recorded with $\mathrm{T} 4$ (shoot pruned at $10 \mathrm{~cm}$ length along with the application of PBZ @ $0.75 \mathrm{~g}$ a.i. / $\mathrm{m}$ canopy diameter, 75\% of RDF, $10 \mathrm{~kg}$ vermicompost, $20 \mathrm{~g}$ of AMC and mango special spray) followed by T9 (109.12), while 
maximum duration for days to maturity (124.40 days) was recorded with control (T1).

TreatmentT4 recorded (13\%) less number of days to maturity compared with other treatments and control. It may be due to early fruit set and growth cause for early maturity.

Soil drenching of paclobutrazol given to regulate cropping tended to reduce the vegetative growth by antagonize the action of gibberellins may be the reason of advancement in flowering and reduction in duration of final harvest. The observation is in close agreement with the report of Tandel and Patel (2011) in mango $c v$. Alphonso, Rajapuri, Kesar and Patel et al., (2016) in mango $c v$. Alphonso.

Number of fruits per tree and Fruit yield (kg/tree)

The observation related to number of fruits per tree are presented in Table 2 revealed that different treatments affected the number of fruits per tree significantly during the year 2017-18 and 2018-19. The maximum number of fruits per tree (148.33) was recorded with treatment $\mathrm{T} 4$ and this was followed by $\mathrm{T} 9$ (124.50) and T10 (91.77). The minimum number of fruits per tree (57.95) was obtained in control which was on par with T2 (61.67) and followed by T7 (73.33).

Fruit yield of individual tree was recorded at the time of harvest. The recorded data on fruit yield was presented in Table 2 revealed that fruit yield tree ${ }^{-1}$ was varied significantly by different treatments during both years of investigation. Pooled mean of two years data showed that the fruit yield per tree was higher $\left(27.58 \mathrm{~kg} \mathrm{tree}{ }^{-1}\right)$ with the treatment of $\mathrm{T} 4$ which was followed by the with $\mathrm{T} 9$ treatment $\left(24.04 \mathrm{~kg} \operatorname{tree}^{-1}\right)$. The lower yield per tree $\left(9.66 \mathrm{~kg}\right.$ tree $\left.\mathrm{e}^{-1}\right)$ was obtained in control which was on par with T2 (12.86 kg tree $\left.{ }^{-1}\right)$.
Pruning enhance the number of fruits per tree and fruit yield $(28 \%$ and $25 \%$ respectively with trees pruned to $20 \mathrm{~cm}$ ). Combination of pruning at $10 \mathrm{~cm}$ along with the application of PBZ @ 0.75 a.i. / m canopy diameter of tree, 75\% RDF, $10 \mathrm{~kg}$ vermicompost, $25 \mathrm{~kg}$ FYM, $20 \mathrm{~g}$ of AMC and micronutrient spray (mango special) enhances the fruit yield significantly over rest of treatments.

This treatment recorded $155.96 \%$ increase in the number of fruits per tree and $166 \%$ increase in fruit yield per tree. Pruning resulted in inducing number of vegetative flushes (Shaban, 2009) and reduced branching density and thus higher fruiting due to better light penetration into tree canopy that increases the photosynthetis efficiency and diverting the photosynthates towards fruit production. Pruning induced enhancement in fruit yields in different mango cultivers has been reported by Pandey and Singh (2008) in mango $c v$. Amrapali, Shaban (2009) in mango $c v$. Zebda, Elkhishen (2015) and Rodge and Pujari (2017) in mango $c v$. Alphonso.

Higher yields in the PBZ treated trees is ascribed due to high flowering intensity, more number of hermaphrodite flowers, increased fruit set and reduced fruit drop, which results in higher fruit number. PBZ is reported to exert influence on overall tree physiology through improved nutrient uptake, partitioning photosynthates to the sites of flowering and fruiting, modifying the plant water balance and altering hormonal balance. The above results are in agreement with Nafees et al., 2010; Tandel and Patel, 2011; Hussen et al., 2012; Sarkar and Rahim, 2012; Upreti et al., 2013; Reddy et al., 2014; Vijaykrishna et al., 2016; Gopu et al., 2017 in different mango cultivars. Enhanced yields may be due to increased photosynthetic rate and carbohydrate accumulation as a result of multifarious role of FYM, vermicompost and biofertilizer. 
Table.1 Effect of combination of different levels of pruning, nutrition and PBZ on fruiting parameters of mango $c v$. Alphonso

\begin{tabular}{|c|c|c|c|c|c|c|}
\hline \multirow[t]{2}{*}{ Treatments } & \multicolumn{3}{|c|}{ Number of fruits per panicle } & \multicolumn{3}{|c|}{ Days to maturity } \\
\hline & 2017-18 & 2018-19 & Mean & 2017-18 & 2018-19 & Mean \\
\hline T1(control) & 0.30 & 1.17 & 0.73 & 123.43 & 125.37 & 124.40 \\
\hline T2(P1+RDF) & 0.60 & 1.53 & 1.07 & 119.37 & 121.07 & 120.22 \\
\hline T3(P1+PBZ1+N1) & 0.87 & 1.73 & 1.30 & 110.63 & 110.47 & 110.55 \\
\hline T4(P1+PBZ1+N2) & 2.20 & 2.83 & 2.52 & 108.73 & 107.53 & 108.13 \\
\hline T5(P1+PBZ2+N1) & 0.97 & 1.27 & 1.12 & 109.47 & 108.87 & 109.17 \\
\hline T6(P1+PBZ2+N2) & 1.31 & 1.39 & 1.33 & 101.10 & 113.47 & 107.28 \\
\hline T7(P2+RDF) & 0.90 & 1.60 & 1.25 & 113.10 & 120.67 & 116.88 \\
\hline T8(P2+PBZ1+N1) & 1.17 & 1.63 & 1.40 & 110.97 & 113.20 & 112.08 \\
\hline T9(P2+PBZ1+N2) & 2.13 & 2.63 & 2.38 & 108.90 & 109.33 & 109.12 \\
\hline T10(P2+PBZ2+N1) & 1.13 & 1.77 & 1.45 & 110.47 & 111.43 & 110.95 \\
\hline T11(P2+PBZ2+N2) & 1.17 & 1.80 & 1.48 & 111.30 & 111.20 & 111.25 \\
\hline S. Em \pm & 0.10 & 0.11 & 0.08 & 1.09 & 1.33 & 1.11 \\
\hline CD at $5 \%$ & 0.29 & 0.31 & 0.23 & 3.20 & 3.92 & 3.15 \\
\hline
\end{tabular}

P1 - Shoot pruning at $10 \mathrm{~cm}$ length; P2 - Shoot pruning at 20cm length.

PBZ1 - @ 0.75 g a.i. / m canopy diameter; PBZ2 - @ 1.25 g a.i. / m canopy diameter

$\mathrm{N} 1-75 \%$ of RDF $+5 \mathrm{Kg}$ Vermi compost $+20 \mathrm{~g}$ Arka microbial consortium + Mango special (spray);

$\mathrm{N} 2-75 \%$ of RDF $+10 \mathrm{Kg}$ Vermi compost $+20 \mathrm{~g}$ Arka microbial consortium + Mango special (spray). 
Table.2 Effect of combination of different levels of pruning, nutrition and PBZ on yield parameters of mango $c v$.Alphonso

\begin{tabular}{|c|c|c|c|c|c|c|}
\hline \multirow[t]{2}{*}{ Treatments } & \multicolumn{3}{|c|}{ Number of fruits per tree } & \multicolumn{3}{|c|}{ Fruit yield (Kg/tree) } \\
\hline & 2017-18 & 2018-19 & Mean & 2017-18 & 2018-19 & Mean \\
\hline T1(control) & 3.24 & 91.67 & 51.95 & 1.05 & 16.07 & 8.66 \\
\hline T2(P1+RDF) & 22.67 & 96.67 & 59.67 & 4.55 & 18.17 & 11.36 \\
\hline T3(P1+PBZ1+N1) & 43.33 & 134.33 & 88.83 & 9.11 & 27.31 & 18.21 \\
\hline T4(P1+PBZ1+N2) & 135.67 & 161.00 & 148.33 & 26.06 & 29.11 & 27.58 \\
\hline T5(P1+PBZ2+N1) & 57.67 & 113.67 & 85.67 & 12.25 & 23.42 & 17.84 \\
\hline T6(P1+PBZ2+N2) & 58.67 & 119.00 & 88.83 & 11.90 & 24.65 & 18.27 \\
\hline T7(P2+RDF) & 39.67 & 103.00 & 73.33 & 8.41 & 18.89 & 13.65 \\
\hline T8(P2+PBZ1+N1) & 43.00 & 131.33 & 87.17 & 9.41 & 26.68 & 18.05 \\
\hline T9(P2+PBZ1+N2) & 103.67 & 145.33 & 124.50 & 21.60 & 25.48 & 24.04 \\
\hline T10(P2+PBZ2+N1) & 65.00 & 118.53 & 91.77 & 12.80 & 23.64 & 18.22 \\
\hline T11(P2+PBZ2+N2) & 48.00 & 118.29 & 83.15 & 11.02 & 23.86 & 17.44 \\
\hline S. Em \pm & 4.83 & 7.81 & 6.07 & 0.97 & 1.55 & 1.25 \\
\hline CD at $5 \%$ & 14.25 & 23.04 & 17.24 & 2.85 & 4.57 & 3.56 \\
\hline
\end{tabular}

P1 - Shoot pruning at $10 \mathrm{~cm}$ length; P2 - Shoot pruning at $20 \mathrm{~cm}$ length.

PBZ1 - @ $0.75 \mathrm{~g}$ a.i./ m canopy diameter; PBZ2 - @ $1.25 \mathrm{~g}$ a.i./ mcanopy diameter.

$\mathrm{N} 1-75 \%$ of RDF + $5 \mathrm{Kg}$ Vermi compost $+20 \mathrm{~g}$ Arka microbial consortium + Mango special (spray);

$\mathrm{N} 2-75 \%$ of RDF + 10Kg Vermi compost + 20 g Arka microbial consortium + Mango special (spray). 
Table.3 Effect of different treatments on economics of mango production $c v$. Alphonso

\begin{tabular}{|c|c|c|c|c|c|c|}
\hline Treatment & $\begin{array}{l}\text { Cost of chemical / } \\
\text { inputs (Rs. /ha) }\end{array}$ & $\begin{array}{c}\text { Total cost of } \\
\text { cultivation }(\mathrm{Rs} / \mathrm{ha})\end{array}$ & $\begin{array}{l}\text { Yield (ton } \\
\text { /ha) }\end{array}$ & $\begin{array}{c}\text { Gross } \\
\text { returns(Rs./ha) }\end{array}$ & $\begin{array}{c}\text { Net } \\
\text { realization } \\
\text { (Rs./ha) }\end{array}$ & $\begin{array}{l}\text { Benefit } \\
\text { cost ratio }\end{array}$ \\
\hline T1(control) & 7,234 & 47,572 & 3.864 & $1,15,920$ & 68,348 & 1.44 \\
\hline T2(P1+RDF) & 8,234 & 48,572 & 4.544 & $1,36,320$ & 87,748 & 1.80 \\
\hline T3(P1+PBZ1+N1) & 32,273 & 72,611 & 7.284 & $2,18,520$ & $1,45,909$ & 2.00 \\
\hline T4(P1+PBZ1+N2) & 42,273 & 82,611 & 11.032 & $3,30,960$ & $2,48,349$ & 3.01 \\
\hline T5(P1+PBZ2+N1) & 35,473 & 75,811 & 7.136 & $2,14,080$ & $1,38,269$ & 1.82 \\
\hline T6(P1+PBZ2+N2) & 45,473 & 85,811 & 7.308 & $2,19,240$ & $1,33,429$ & 1.55 \\
\hline T7(P2+RDF) & 8,234 & 48,572 & 5.460 & $1,63,800$ & $1,15,228$ & 2.37 \\
\hline T8(P2+PBZ1+N1) & 32,273 & 72,611 & 7.220 & $2,16,600$ & $1,43,989$ & 1.98 \\
\hline T9(P2+PBZ1+N2) & 42,273 & 82,611 & 10.016 & $3,00,480$ & $2,17,869$ & 2.63 \\
\hline T10(P2+PBZ2+N1) & 35,473 & 75,811 & 7.288 & $2,18,640$ & $1,42,829$ & 1.88 \\
\hline T11(P2+PBZ2+N2) & 45,473 & 85,811 & 6.976 & $2,09,280$ & $1,23,469$ & 1.43 \\
\hline
\end{tabular}

Basic cost of cultivation - Rs. 40,338/ha

Price of fruits - Rs. 30/kg

P1 - Shoot pruning at $10 \mathrm{~cm}$ length; P2 - Shoot pruning at $20 \mathrm{~cm}$ length.

PBZ1 - @ $0.75 \mathrm{~g}$ a.i./ m canopy diameter; PBZ2 - @ $1.25 \mathrm{~g}$ a.i./ mcanopy diameter.

$\mathrm{N} 1-75 \%$ of RDF $+5 \mathrm{Kg}$ Vermicompost $+20 \mathrm{~g}$ Arka microbial consortium + Mango special (spray);

$\mathrm{N} 2-75 \%$ of RDF $+10 \mathrm{Kg}$ Vermicompost $+20 \mathrm{~g}$ Arka microbial consortium + Mango special (spray). 
As explained by Chandra and Shivraj, 1972, yield enhancement can also be attributed to the fact that enhanced uptake level of nutrients such as nitrogen by bioferilizers could have diverted the photo assimilates to the developing flower buds and helped in the conversion of flowers to more femaleness to produce higher number of fruits which in turn also increase the weight of fruit and yield. Biofertilizer has currently attained a special significance because of their stimulation effects on the rate of biosynthesis of the plant growth regulators (auxin, gibberellins and cytokinin), which are helpful to increase the metabolic activity of plant and simultaneously, to increase the fruit set and yield (Goldwin, 1986). Increase in yield and yield attributing characters with reduced NPK doses in association with organic manure and biofertilizers may be due to the optimum supply of plant nutrients and growth hormones at desired amount during entire period of fruit growth, ultimately increase in accumulation of photosynthate and resulted into increase in yield of fruits as reported by Balakrishna et al., (2001) in custard apple and Yadavet al., (2011) in mango $c v$. Amrapali. INM induced higher yields in different mango cultivers has been recorded by Omar and Belal (2007), Patel et al., (2005), Kunduet al., (2011), Singh and Banik (2011), Yadav et al., (2011), Mohitkumar and Rajeshkumar (2014), Khamis et al., (2017), Sau et al., (2017) and Mohitkumar et al., (2018).

The combination of pruning, PBZ and INM enhanced fruit yield is expected to be cumulative in increasing the yields as evident from our results.

\section{Benefit cost ratio}

The calculated data on benefit cost ratio was presented in Table 3 indicated that treatments has shown significant effect on benefit cost ratio. It was maximum (3.06) with T4 followed by T9 (2.63) and T7 (2.37) and recorded minimum with control (1.44).Although, fruit yield was high in the combination treatments, but the benefit: cost ratio was found to be at par with pruning treatment. It was mainly due to the higher cost of vermicompost. Similar conformational results are obtained by Reddy and Kurian (2014) in mango $c v$. Alphonso, Dutta et al., (2016) and Sau et al., (2017) in mango $c v$. Himsagar, Talathi et al., (2015) and Singh et al., (2018) in mango cv. Amrapali.

As evident from analysis of benefit cost ratio, treatment T4 is best suitable to the farmers for getting higher profits by adopting it.

On the basis of experimental findings, it can be concluded that among the different treatment combinations the treatment pruning at $10 \mathrm{~cm}$ length in association with the soil drenching of PBZ @ 0.75g a.i./ m canopy diameter and application of $75 \%$ of RDF, $10 \mathrm{~kg}$ vermicompost, $20 \mathrm{~g}$ of AMC and mango special spray was most promising for regulating and getting higher yields in high density orchard of mango $c v$. Alphonso.

\section{Acknowledgements}

The authors are thankful to the Dean, College of Horticulture, Bengaluru for providing necessary facilities for smooth conduction and completion of research work.

\section{References}

Anonymous, 2018. Indian Horticulture Database. National Horticulture Board, Gurgaon, Haryana.

Balakrishnan, S., Selvarajan, M. and Siddeswaran, K. 2001. Effect of biofertilizers in custard apple. South Indian Horticulture 49: 185186.

Chandra, R. and Shivraj, J. 1972. Influence of exogenous hormones on flowering, flower shedding and fruit set of chilli. Andhra 
Agricultural Journal, 19: 34-44.

Deepasamant, Kishore. K. and Singh, H. S. 2018.Assessing effectiveness of 'Arka Mango Special' for improving yield and quality of mango variety 'Banganpalli' in lateritic soils of Odisha, India. International Journal of Current Microbiology Applied Science 7(1): 168173.

Elkhishen, M. A. 2015.Effect of pruning severity on flowering and fruiting of mango (Mangifera indica) $c v$. Alphonso in offYear Season. Egyptian Journal Horticulture, 42(2): 785 - 794.

Goldwin, G. K. 1986.Use of hormone setting sprays with monoculture orchards to give more regular cropping. Acta Horticulture 179: 343-348.

Gopu, B., Balamohan, T. N., Swaminathan, V., Jeyakumar, P. and Soman, P. 2017. Effect of growth retardants on yield and yield contributing characters in mango (Mangifera indica L.) $c v$. Alphonso under ultra high density plantation. International Journal of Current Microbiology Applied Science, 6(11): 3865-3873.

Hussen, S., Kuswanto, S. A. and Basuki, N. 2012. Induction of flowering and yield of mango hybrids using paclobutrazol. Journal of Agriculture and Food Technology, 2(9): 153-158.

Jannoyer, M. and Lauri, P. 2009. Young flush thinning in mango $c v$. Cogshall controls canopy density and production. Acta Horticulture, 820: 395-402.

Khamis, M. A., Sharaf, M. M., Abd-EL-Latif, F. M., Habashy, S. I. and Kelani, R. A., 2017, Impact of inorganic and bio-organic fertilization on growth, yield and fruit quality of young fruitful mango trees $c v$. FajriKalan. Middle East Journal of Agriculture Research, 6(2):340-347.

Kundu, S., Datta, P., Mishra, J., Rashmi, K. and Ghosh, B. 2011. Influence of biofertilizer and inorganic fertilizer in pruned mango orchard $c v$. Amrapali. Journal of Crop and Weed, 7(2): 100-103.

Kurian, R. M., Reddy, Y. T. N., Sonkar, R. K. and Reddy, P. P. 2001. Effect of paclobutrazol on source-sink relationship in mango (Mangifera indica L.). Journal of Applied
Horticulture, 3(2): 88-90.

Lina, D. P. and Protacio, C. M. 2015.Phenology of jackfruit (Artocarpus heterophyllus) and effects of paclobutrazol on off-season fruit production. Acta Horticulture 1088: 495500 .

Mohitkumar, Kumar, R., Singh, R. and Kumar, L. 2018. Effect of Organic manures on physical and chemical characteristics of mango $c v$. Dashehari at ambient storage conditions. International Journal of Current Microbiology Applied Science, 7(1): 31-39.

Mohitkumar and Rajeshkumar 2014.Response of organic manures on post harvest quality of mango (Mangifera indica) $c v$. Dashehari. Agricultural Science Digest, 34 (4): 310 312.

Nafees, M., Muhammad, F., Saeedahmad, Khan, M. A., Jamil, M. and Aslam, M. N. 2010.Paclobutrazol soil drenching suppresses vegetative growth, reduces malformation, and increases production in mango. International Journal of Fruit Science, 10:431-440.

Omar, A. E. D. and Belal, E. B. A. 2007 Effect of organic, inorganic and bio-fertilizer application on fruit yield and quality of mango trees (Mangifera indica L. $c v$. Sukari) in Balteem, Kafr El- Sheikh. Egyptian Journal of Agricultural Research Kafrelsheikh University, 33 (4): 857-872.

Pandey, S. N. and Singh, O. P. 2008.Pruning for sustaining productivity of mango (Mangifera indica L.) $c v$. Amrapali in high density plantation. Orissa Journal of Horticulture, 36: 26-31.

Patel, G. D., Patel, B. N., Desai, K. D., Patel, N. K. and Patel, B. B. 2016. Influence of paclobutrazol for earliness in mango $c v$. Alphonso. International Journal of Science and Environmental Technology, 5(5): 2713 - 2718.

Patel, V. B., Singh, S. K., Asrey, R. and Sharma, Y. K. 2005. Response of organic manures and biofertilizers on growth, fruit yield and quality of mango $c v$. Amrapali under high density orcharding. Karnataka Journal of Horticulture, 1(3): 51-56.

Purseglove, J. W. 1972.Mangoes west of India. Acta Horticulture, 24:107-174. 
Reddy, Y. T. N., Upreti, K. K. and Shivu prasad, S. R. 2014. Response of paclobutrazol treatment on flowering, fruit maturity, yield and quality of mango (Mangifera indica L.) $c v$. Totapuri. Indian Journal of Agicultural Science, 84(10): 1231-1235.

Rodge, B. M. and Pujari, K. H. 2017.Studies on effect of pruning on reproductive shoots and yield of mango $c v$. Alphonso. Asian Journal of Horticulture, 12(2): 218-222.

Sarker, B. C and Rahim, M. A. 2012.Vegetative growth, harvesting time, yield and quality of mango (Mangifera indica L.) as influenced by soil drench application of paclobutrazol. Bangladesh Journal of Agricultural Research, 37(2): 335- 348.

Shaban, A. E. A. 2009. Effects of summer pruning and $\mathrm{GA}_{3}$ spraying on inducing flowering and fruiting of Zebda mango trees. World Journal of Agricultural Sciences, 5(3):337-344.

Singh, S. R. and Banik, B. C. 2011. Response of integrated nutrient management on flowering, fruit setting, yield and fruit quality in mango (Mangifera indica L.) $c v$. Himsagar. The Asian Journal of Horticulture, 6(1): 151-155.

Singh, T. K., Divyasingh, Jain, A.K. and Bose U.S. 2018.Effect of pruning with paclobutrazol application for growth, yield and quality of mango (Mangifera indica L.) cv. Amrapali. International Journal of Current Microbiology Applied Science, 7(8): 883-888.

Singh, S. K., Sharma, R. R., Srivastav, M. and Patel, V. B. 2009 Effect of pruning on morpho-physiological parameters and microclimate under high density planting of mango (Mangifera indica L.). Indian Journal of Agrcultural Sciences, 79(8): 632-635.

Sau, S., Mandal, P., Sarkar, T., Das, K. and Datta. P. 2017. Influence of bio-fertilizer and liquid organic manures on growth, fruit quality and leaf mineral content of mango cv. Himsagar. Journal of Crop and Weed, 13(1): 132-136.

Tandel, Y. N. and Patel, N. L. 2011.Effect of chemicals on growth, yield and economics of mango (Mangifera indica L.). Karnataka Journal of Agricultural Sciences, 24 (3): 362 - 365.

Upreti, K. K., Reddy, Y. T. N., Shivu prasad, S. R., Bindu, G. V., Jayaram, H. L. and Rajan, S. 2013. Hormonal changes in response to paclobutrazol induced early flowering in mango $c v$. Totapuri. Scientia Horticulturae, 150: 414-418.

Vijaykrishna, G. V., Bhagwan, A., Kumar, M. R. and Shankar, A. S. 2016. Effect of flower enhancing plant growth regulators and fruit set improving chemicals on flowering and fruit set of mango (Mangifera indica) $c v$. Banganpalli. International Journal of Science and Nature, 7(1): 81-88.

Yadav, A. K., Singh, J. K. and Singh, H. K. 2011.Studies on integrated nutrient management in flowering, fruiting, yield and quality of mango $c v$. Amrapali under high density orchading. Indian Journal of Horticulture, 68(4):453-460.

Yadav, I. S. 1997.Mango research in India in the past 50 years. Indian Horticulture, 42(2): $10-17$.

\section{How to cite this article:}

Usha Rani, K., M.K. Honnabyraiah, J. DinakaraAdiga, T. Sakthivel, Ashok, S. Alur and Halesh, G.K. 2019. Effect of Combination of Different Levels of Pruning, Nutrition and Paclobutrazol on Yield and Economics of Mango (Mangifera indica L.) cv. Alphonso. Int.J.Curr.Microbiol.App.Sci. 8(11): 995-1004. doi: https://doi.org/10.20546/ijcmas.2019.811.117 